УДК 635.655:631.526.3:631.53.048 (477)

(C) 2017

Лотиш I. I., аспірант

(науковий керівник - доктор сільськогосподарських наук, професор М. Я. Шевніков)

Полтавська державна аграрна академія

\title{
ФОРМУВАННЯ ПЛОЩІ ЛИСТКОВОЇ ПОВЕРХНІ ПОСІВІВ СОЇ ЗАЛЕЖНО ВІД СОРТУ, СПОСОБУ СІВБИ ТА НОРМИ ВИСІВУ В УМОВАХ НЕДОСТАТНЬОГО ЗВОЛОЖЕННЯ ЛІСОСТЕПУ
}

\section{Рецензент - доктор сільськогосподарських наук, професор П. В. Писаренко}

\begin{abstract}
Одержання максимально можливої для того чи іншого сорту сої продуктивності безпосередньо залежить від складових технологій, які забезпечують формування оптимальної площуі листкової поверхні та тривалості ї̈ фотосинтетичної активності. Вивчення фотосинтетичного потенціалу посівів сортів сої виявило, щчо найбільший показник був на ділянках з нормою висіву 800 тис./га: за рядкової сівби - 2,192,34 млн м $^{2}$ дн/га, за широкорядної сівби - 2,162,27 млн м $^{2}$ дн/га. Інтенсивність фотосинтезу залежно від варіантів досліду коливалася: за рядкового способу сівби в межах від 11,55 до 12,40 мг $\mathrm{CO}_{2} \partial^{2} /$ год., за широкорядного способу сівби - від 11,33 до 12,06 мг $\mathrm{CO}_{2}$ дм²/год. Залежно від норми висіву та способу сівби листковий індекс становив для сортів відповідно: Романтика - від 3,89 до

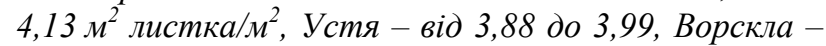
від 3,80 до 3,92 м $^{2}$ листка/м².
\end{abstract}

Ключові слова: соя, строки сівби, способи сівби, норма висіву, фотосинтез.

Постановка проблеми. У зв'язку з інтенсифікацією виробництва сої виникає питання 3'ясування елементів технології вирощування, які мають забезпечити іiї високу продуктивність. Серед них вирішальне значення мають строки, спосіб сівби і норма висіву сої.

Правильне розміщення рослин сої на площі повинно задовольняти основну вимогу - найкраще освітлення листкової поверхні. У сприятливих умовах довжини світлового дня соя потребує інтенсивного освітлення, за нестачі якого соя не цвіте. Як світлолюбна культура, вона формує високу урожайність лише за оптимальних для конкретного сорту площі живлення і густоті рослин, освітленості, забезпеченні вологою і поживними речовинами, що, в свою чергу, визначає облистяність, інтенсивність фотосинтезу, утворення бобів, кількість бобів і насіння, обумовлює величину та якість насіння $[1,2,3]$.

Аналіз основних досліджень і публікацій, у яких започатковано розв'язання проблеми. Накопичення посівами сухої речовини за вегетаційний період характеризує ступінь їх продукти- вності. У період формування та наливу зерна важливе значення має трансформація продуктів фотосинтезу і темпи накопичення сухої речовини. В цей час підсистеми продукуюча та зберігаюча тісно взаємопов'язані і врожайність зерна формується в результаті його взаємодії з фотосинтетичним апаратом. Спрямованість процесу накопичення сухої речовини та перерозподіл між продукуючою та зберігаючою системами $\epsilon$ однією 3 оцінок рівня продуктивності. Тому більш точну інформацію про хід і особливості продуційного процесу можна отримати за допомогою визначення акумуляції сухої речовини рослинами впродовж вегетаційного періоду $[4,5,7]$.

Найвищі й найкращі за якістю продукції сільськогосподарських рослин можна отримати в посівах 3 оптимальною за розмірами площею листків, оптимальним ходом іiі формування i структурою $[2,6]$. Оптимальний ріст листкової поверхні та формування високого фотосинтетичного потенціалу листя в значній мірі залежать від обгрунтованості технологій вирощування, які забезпечують тривалішу роботу листкового апарату.

Вважається, що основою, завдяки якій внаслідок фотосинтетичної діяльності створюється врожай сої, є формування оптимальної площі листової поверхні. Листкова поверхня засвоює сонячну енергію і синтезує органічні сполуки, які йдуть на формування нових органів рослин $\mathrm{i}$ врожаю. Згідно з результатами досліджень, проведених у Лісостепу України, відомо, що оптимальна площа листової поверхні для сої повинна становити 40-50 тис. ${ }^{2} /$ га. Якщо площа листової поверхні менша, то оптико-біологічна структура посіву не оптимізована і тому ФАР використовується не раціонально. Проте й більша площа листової поверхні є небажаною, оскільки в результаті взаємозатінення значна частина листків у нижньому ярусі обпадає, а решта працює не ефективно $[1,3]$. Дослідниками встановлено, що цей показник у сої може варіювати в досить широких межах залежно від генотипу сорту, еколо- 


\section{СТОРІНКА МОЛОДОГО ВЧЕНОГО}

гічних умов регіону та агротехнічних заходів по iї вирощуванню [4].

Метою досліджень було встановлення оптимальної густоти посіву сої шляхом правильного вибору норми висіву і способу сівби, які б забезпечили оптимальний ріст і розвиток рослин та високу продуктивність.

Методика проведення досліджень. Під час визначення строку сівби враховували, що ранній строк відповідає мінімальній температурі грунту $\left(8-10{ }^{\circ} \mathrm{C}\right)$, в разі якої можливе проростання насіння сої. Оптимальний строк сівби визначали у випадку прогрівання грунту до $+12-14{ }^{\circ} \mathrm{C}$. Пізній строк сівби відповідав підвищенню температури грунту до $+16-18^{\circ} \mathrm{C}$. У перших двох випадках обов'язково враховували також достатнє вологозабезпечення верхнього шару грунту. Пізній строк сівби частіше супроводжувався низькою вологістю посівного шару грунту. Метеорологічні умови в роки проведення дослідів були різноманітними і сповна характеризували особливості клімату даної місцевості.

Результати досліджень. У дослідженнях ми вивчали дію строків, способів сівби та норм висіву на активізацію процесу фотосинтезу, зокрема на формування площі листової поверхні (табл. 1). Передусім варто зазначити сортову специфіку у прояві ознаки листкової поверхні. Нами було виявлено, що сорти сої не дуже різнилися за показником площі листків, більш суттєвий вплив здійснювали норми висіву та спосо- би сівби. За рядкового способу сівби та норми висіву 500 тис./га площа листкової поверхні становила 40,1-41,5 тис. м²/га. Збільшена норма висіву 600 тис./га сприяла підвищенню цього показника до 41,3-43,5 тис. $\mathrm{M}^{2} /$ га, 700 тис./га 43,7-46,3 тис. $\mathrm{m}^{2} /$ га, 800 тис./га - 44,3-44,8 тис. $\mathrm{m}^{2} /$ га. За широкорядного способу сівби та норми висіву 500 тис./га площа листкової поверхні становила $30,5-40,9$ тис. м $^{2}$ га.

Збільшена норма висіву 600 тис./га сприяла підвищенню цього показника до 40,5-42,8 тис. $\mathrm{m}^{2} /$ га, 700 тис./га - 43,2-45,7 тис. $\mathrm{м}^{2} /$ га, 800 тис./га - 43,7-44,5 тис. м²/га. Рядковий спосіб сівби формував збільшену площу листкової поверхні в порівнянні з широкорядним. Серед сортів незначне підвищення площі листя спостерігалося за висіву сорту Устя.

Для фотосинтезу і сполученого з ним процесу біологічної фіксації азоту важливим фактором $\epsilon$ проникнення світла до листків сої усіх ярусів. Лише за оптимальної густоти у посіві формується такий габітус рослини, який сприяє доброму освітленню, рівномірному утворенню на ній листків, бобів та насінин, високій інтенсивності фотосинтезу та врожайності насіння. Для врахування процесу фотосинтезу як основи створення біологічної речовини слід врахувати такі показники, як формування фотосинтетичного потенціалу, визначення чистої продуктивності фотосинтезу, встановлення інтенсивності фотосинтезу i листкового індексу.

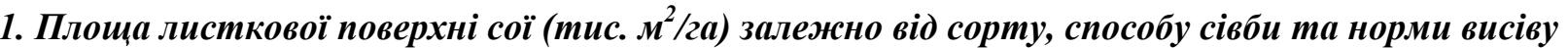

(середнє за 2013-2015 pp.)

\begin{tabular}{|c|c|c|c|}
\hline \multirow{2}{*}{ Норма висіву, тис./га } & \multicolumn{3}{|c|}{ Сорт } \\
\cline { 2 - 4 } & Романтика & Устя & Ворскла \\
\hline \multicolumn{4}{|c|}{ Рядковий спосіб сівби, 15 см } \\
\hline 500 & 40,1 & 41,5 & 40,8 \\
\hline 600 & 41,3 & 43,5 & 42,7 \\
\hline 700 & 43,7 & 46,3 & 45,4 \\
\hline 800 & 44,8 & 44,8 & 44,3 \\
\hline \multicolumn{5}{|c|}{ Широкорядний спосіб сівби, 45 см } \\
\hline 500 & 39,5 & 40,9 & 39,9 \\
\hline 600 & 40,5 & 42,8 & 42,1 \\
\hline 700 & 43,2 & 45,7 & 44,8 \\
\hline 800 & 44,5 & 44,5 & 43,7 \\
\hline
\end{tabular}




\section{СТОРІНКА МОЛОДОГО ВЧЕНОГО}

2. Формування фотосинтетичного потенціалу (ФП, млн $м^{2}$ дн/zа) та чистої продуктивності фотосинтезу (ЧПФ, г/м за добу) залежно від сорту, способу сівби та норми висіву

(середнс за 2013-2015 рр.)

\begin{tabular}{|c|c|c|c|c|c|c|}
\hline \multirow{2}{*}{$\begin{array}{c}\text { Норма висіву, } \\
\text { тис./га }\end{array}$} & \multicolumn{6}{c|}{ Сорт } \\
\cline { 2 - 7 } & \multicolumn{2}{|c|}{ Романтика } & \multicolumn{2}{c|}{ Устя } & \multicolumn{2}{c|}{ Ворскла } \\
\cline { 2 - 7 } & ФП & ЧПФ & ФП & ЧПФ & ФП & ЧПФ \\
\hline \multicolumn{7}{|c|}{ Рядкий спосіб сівби, 15 см } \\
\hline 500 & 2,29 & 10,13 & 2,22 & 9,80 & 2,17 & 9,60 \\
\hline 600 & 2,32 & 10,23 & 2,23 & 9,86 & 2,18 & 9,62 \\
\hline 700 & 2,32 & 10,24 & 2,24 & 9,87 & 2,18 & 9,64 \\
\hline 800 & 2,34 & 10,31 & 2,24 & 9,89 & 2,19 & 9,66 \\
\hline \multicolumn{7}{|c|}{ Широкорядний спосіб сівби, 45 см } \\
\hline 500 & 2,23 & 9,82 & 2,18 & 9,60 & 2,13 & 9,44 \\
\hline 600 & 2,25 & 9,93 & 2,19 & 9,66 & 2,14 & 9,47 \\
\hline 700 & 2,25 & 9,94 & 2,19 & 9,67 & 2,15 & 9,50 \\
\hline 800 & 2,27 & 10,03 & 2,20 & 9,71 & 2,16 & 9,54 \\
\hline
\end{tabular}

Показник фотосинтетичного потенціалу характеризує потенційні можливості фотосинтетичного листкового апарату рослин сортів сої і $€$ сумою щоденних показників площі листків посіву за весь вегетаційний період чи за його частину. В наших дослідженнях фотосинтетичний потенціал за рядкового способу сівби сорту Романтика 3 нормою висіву 500 тис./га становив 2,29 млн м ${ }^{2}$ дн/га. Збільшення норми висіву від 600 до 800 тис/га сприяло його підвищенню до 2,32-2,34 млн. м² дн/га. У сорту Устя за відповідного збільшення норми висіву становило 2,22; 2,$23 ; 2,24 ; 2,24$ млн м² дн/га, у сорту Ворскла 2,17-2,19 млн м² дн/га відповідно (табл. 2). Позитивна динаміка збільшення показника фотосинтетичного потенціалу спостерігалася за широкорядного способу сівби з міжряддями 45 см. На ділянках 3 нормою висіву 500 тис./га сорту Романтика показник фотосинтетичного потенціалу посіву становив 2,23 млн м² дн/га, сорту Устя 2,18 , сорту Ворскла - 2,13 млн м² дн/га.

Збільшення норми висіву до 600 тис./га збільшило цей показник до 2,25; 2,19 та 2,14 млн м² дн/га відповідно сортів. За норми висіву 700 тис./га фотосинтетичний потенціал посіву становив відповідно 2,25; 2,19 та 2,15 млн м дн/га, за норми висіву 800 тис./га $-2,27 ; 2,20$ та 2,16 млн м ${ }^{2}$ дн/га.

Отже, вивчення фотосинтетичного потенціалу посівів усіх досліджуваних сортів сої виявило, що найбільший показник був на ділянках 3 нормою висіву 800 тис./га: за рядкової сівби - 2,19-
2,34 млн м² дн/га, за широкорядної сівби - 2,162,27 млн м ${ }^{2}$ дн/га. Крім фотосинтетичного потенціалу важливим показником фотосинтезу в посівах $є$ чиста продуктивність фотосинтезу. Чиста продуктивність фотосинтезу являє собою відношення приросту маси сухої речовини рослин за певний проміжок часу до одиниці листкової поверхні. Значення даного показника в наших дослідженнях залежно від варіантів досліду коливалося в межах від 9,44 г/м² за добу (с. Ворскла, широкорядного способу сівби, норма висіву 500 тис./га) до 10,31 г/м² за добу (с. Романтика, рядкового способу сівби, норма висіву 800 тис./га).

У наших дослідженнях чиста продуктивність фотосинтезу за рядкового способу сівби сорту Романтика 3 нормою висіву 500 тис./га становила $10,13 \Gamma / \mathrm{m}^{2}$ за добу. Збільшення норми висіву від 600 до 800 тис./га сприяло їі підвищенню до 10,23-10,31 г/м² за добу. У сорту Устя за відповідного збільшення норми висіву становило

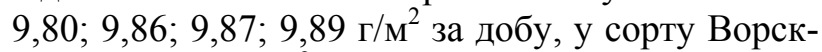
ла $-9,60-9,66$ г/м² за добу відповідно.

Позитивною також була динаміка збільшення показника чистої продуктивності фотосинтезу за широкорядного способу сівби 3 міжряддями 45 см. На ділянках 3 нормою висіву 500 тис./га сорту Романтика показник чистої продуктивності фотосинтезу посіву становив 9,82 г/м ${ }^{2}$ за добу,

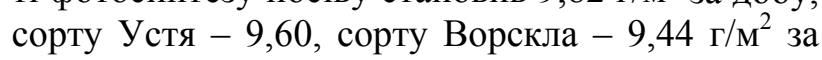
добу. Збільшення норми висіву до 600 тис./га збільшило цей показник до 9,93; 9,66 та 9,47 г/м² 
за добу відповідно сортів. За норми висіву 700 тис./га чиста продуктивність фотосинтезу посіву становила відповідно 9,94; 9,67 та

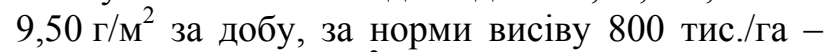
10,$03 ; 9,71$ та 9,54 г/м² за добу.

Для пояснення показників фотосинтетичного потенціалу та чистої продуктивності фотосинтезу визначали інтенсивність фотосинтезу і листковий індекс. Інтенсивність фотосинтезу, або його швидкість, являє собою поглинання вуглекислоти листком у денний світловий час у розрахунку на одиницю його поверхні (мг $\mathrm{CO}_{2}$ дм²/год.). Значення цього показника в наших дослідженнях залежно від варіантів досліду коливалося: за рядкового способу сівби в межах від 11,55 мг $\mathrm{CO}_{2}$ дм²/год. (с. Ворскла, норма висіву 500 тис./га) до 12,40 мг $\mathrm{CO}_{2}$ дм²/год. (с. Романтика, норма висіву 800 тис./га), за широкорядного способу сівби - від 11,33 мг $\mathrm{CO}_{2}$ дм²/год. (с. Ворскла, норма висіву 500 тис./га) до 12,06 мг $\mathrm{CO}_{2}$ дм $^{2} /$ год. (с. Романтика, норма висіву 800 тис./га) (табл. 3).

Дослідженнями встановлено, що інтенсивність фотосинтезу за рядкового способу сівби сорту Романтика 3 нормою висіву 500 тис./га

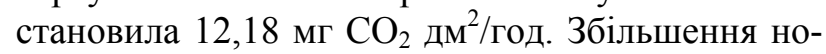
рми висіву від 600 до 800 тис./га сприяло їі підвищенню до 12,31-12,40 мг $\mathrm{CO}_{2}$ дм ${ }^{2} /$ год. У сорту Устя за відповідного збільшення норми висіву інтенсивність фотосинтезу становила 11,79; 11,$87 ; 11,88 ; 11,90$ мг $\mathrm{CO}_{2}$ дм$^{2} /$ год., у сорту Вор- скла - 11,55; 11,57; 11,59; 11,63 мг $\mathrm{CO}_{2}$ дм²/год. $^{2}$ відповідно. За широкорядного способу сівби сорту Романтика цей показник 3 нормою висіву 500 тис./га становив 11,81 мг $\mathrm{CO}_{2}$ дм²/год. За умови збільшення норми висіву 3600 до 800 тис./га становив 11,95-12,06 мг $\mathrm{CO}_{2}$ дм²/год., сорту Устя - відповідно 11,55 мг $\mathrm{CO}_{2}$ дм²/год. та 11,62-11,68 мг $\mathrm{CO}_{2}$ дм²/год., сорту Ворскла 11,33 мг $\mathrm{CO}_{2}$ дм ${ }^{2} /$ год. та $11,39-11,47$ мг $\mathrm{CO}_{2}$ дм ${ }^{2} /$ год.

Листковий індекс або листкову забезпеченість сої ми визначали шляхом відношення сумарної листкової площі рослин (м² листка) до $1 \mathrm{~m}^{2}$ посівної ділянки. Наші дослідження показали, що листковий індекс сортів сої мав найбільше значення у фазі зеленої стиглості бобів. Далі в результаті самозатінення рослин і часткового пожовтіння нижніх листків, це значення знижувалося. Залежно від норми висіву та способу сівби листковий індекс становив для сортів відповідно: Романтика - від 3,89 до 4,13 м² листка/м², Устя від 3,88 до 3,99, Ворскла - від 3,80 до 3,92 м² листка/ $\mathrm{M}^{2}$.

Залежно від норми висіву сорту Романтика листковий індекс за рядкового способу сівби підвищився $34,05 \mathrm{~m}^{2}$ листка/ $\mathrm{m}^{2}$ за норми висіву 500 тис./га до 12,40 м² листка/ м $^{2}$ за норми висіву 800 тис./га. Для сорту Устя ці показники мали значення 3,93 і 3,99 м² листка/м², для сорту Вор-

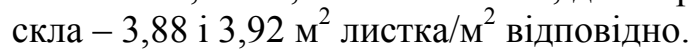

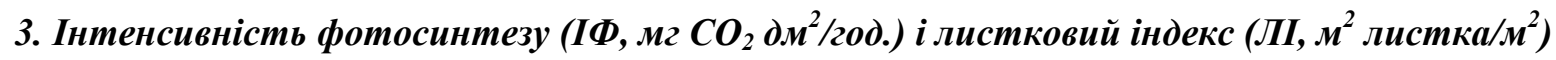
залежно від сорту, способу сівби та норми висіву (середнс за 2013-2015 рр.)

\begin{tabular}{|c|c|c|c|c|c|c|}
\hline \multirow{2}{*}{$\begin{array}{c}\text { Норма висіву, } \\
\text { тис./га }\end{array}$} & \multicolumn{6}{c|}{ Сорт } \\
\cline { 2 - 7 } & \multicolumn{2}{|c|}{ Романтика } & \multicolumn{2}{c|}{ Устя } & \multicolumn{2}{c|}{ Ворскла } \\
\cline { 2 - 7 } & ІФ & ЛІ & ІФ & ЛІ & ІФ & ЛІ \\
\hline \multicolumn{7}{|c|}{ Рядковий спосіб сівби, 15 см } \\
\hline 500 & 12,18 & 4,05 & 11,79 & 3,93 & 11,55 & 3,88 \\
\hline 600 & 12,31 & 4,08 & 11,87 & 3,95 & 11,57 & 3,88 \\
\hline 700 & 12,32 & 4,11 & 11,88 & 3,97 & 11,59 & 3,90 \\
\hline 800 & 12,40 & 4,13 & 11,90 & 3,99 & 11,63 & 3,92 \\
\hline \multicolumn{7}{|c|}{ Широкорядний спосіб сівби, 45 см } \\
\hline 500 & 11,81 & 3,89 & 11,55 & 3,88 & 11,33 & 3,80 \\
\hline 600 & 11,95 & 3,94 & 11,62 & 3,90 & 11,39 & 3,83 \\
\hline 700 & 11,96 & 3,97 & 11,63 & 3,93 & 11,44 & 3,85 \\
\hline 800 & 12,06 & 4,00 & 11,68 & 3,92 & 11,47 & 3,87 \\
\hline
\end{tabular}




\section{СТОРІНКА МОЛОДОГО ВЧЕНОГО}

За широкорядного способу сівби листковий індекс був нижчим і становив для сорту Романтика 3 нормою висіву 500 тис./га 3,89 м² листка/м², 3 нормою висіву 600 тис./га - 3,94 м² листка/м², 3 нормою висіву 700 тис./га - 3,97 м² листка/ $\mathrm{M}^{2}, 3$ нормою висіву 800 тис./га - 4,00 м² листка/м². Для сорту Устя ці показники мали відповідне значення - 3,88; 3,90; 3,93 і 3,92 м² листка/м², для сорту Ворскла - 3,80; 3,83; 3,85 і $3,87 \mathrm{~m}^{2}$ листка/ $\mathrm{M}^{2}$.

Соя $є$ досить чутливою до фотоперіодизму та інтенсивності освітлення. Одержання максимально можливої для того чи іншого сорту сої продуктивності безпосередньо залежить від тих складових технологій, які забезпечують формування оптимальної площі листкової поверхні та тривалості їі фотосинтетичної активності. Вивчення фотосинтетичного потенціалу посівів усіх досліджуваних сортів сої виявило, що найбільший показник був на ділянках 3 нормою висіву 800 тис./га: за рядкової сівби - 2,19-2,34 млн м² дн/га, за широкорядної сівби - 2,16-2,27 млн м² дн/га. Інтенсивність фотосинтезу за рядкового способу сівби сорту Романтика 3 нормою висіву 500 тис./га становила 12,18 мг $\mathrm{CO}_{2}$ дм²/год. Збільшення норми висіву від 600 до 800 тис./га сприяло іiі підвищенню до 12,3112,40 мг $\mathrm{CO}_{2}$ дм²/год. Інтенсивність фотосинтезу залежно від варіантів досліду коливалася: за рядкового способу сівби в межах від 11,55 мг $\mathrm{CO}_{2}$ дм$^{2} /$ год. до 12,40 мг $\mathrm{CO}_{2}$ дм²/год., за широкорядного способу сівби - від 11,33 мг $\mathrm{CO}_{2}$ дм²/год. до 12,06 мг $\mathrm{CO}_{2}$ дм²/год. Залежно від норми висіву та способу сівби листковий індекс становив для сортів відповідно: Романтика - від 3,89 до 4,13 м² листка/м², Устя - від 3,88 до 3,99, Ворскла - від 3,80 до 3,92 м $^{2}$ листка/ $\mathrm{m}^{2}$.

\section{Висновки:}

1. Соя чутлива до зміни величини i форми

\section{БІБЛІОГРАФІЯ}

1. Бахмат O. M. Урожайність насіння сої залежно від сорту і системи удобрення / О. М. Бахмат, О. С. Чинчик // Зб. наук. праць ПДАТУ. Кам'янець-Подільський, 2005. - Вип. 13. C. 102-105.

2. Бондаренко Н. Ф. Моделирование продуктивности агроэкосистем : монография / Н. Ф. Бондаренко. - М. : Мир, 1982. - 130 с.

3. Калініченко В. М., Писаренко П. В. Модель розвитку сої за фенологічними фазами / В. М. Калініченко, П. В. Писаренко // Вісник ПДАА. - 2004. - №1. - С. 10-16.

4. Слободян С. М. Технологія вирощування скоростиглого сорту сої / С. М. Слободян, Н. М. Трикіна, Ю. Л. Пернак // Наук.-інформ. площі живлення рослин у посіві. За оптимальної густоти і площі живлення рослин основна кількість бобів формується на головному пагоні, у зріджених - на бокових гілках. Негативна дія надмірного загущення призводить до вилягання, передчасного пожовтіння i опадання листків. Зміна норми висіву від 500 до 800 тис./га схожих насінин за звичайної рядкової сівби сприяла збільшенню висоти кріплення нижніх бобів від 13,9 до 15,7 см, за широкорядної сівби з міжряддями 45 см - від 14,3 до 14,4 см.

2. Важливою умовою одержання високого рівня врожайності насіння сої є оптимальна густота стояння рослин за відповідними способами сівби та величини листкового апарату зокрема. Одержання максимально можливої для того чи іншого сорту сої продуктивності безпосередньо залежить від тих складових технологій, які забезпечують формування оптимальної площі листкової поверхні та тривалості їі фотосинтетичної активності.

3. Вивчення фотосинтетичного потенціалу посівів всіх досліджуваних сортів сої виявило, що найбільший показник був на ділянках 3 нормою висіву 800 тис./га: за рядкової сівби - 2,192,34 млн м² дн/га, за широкорядної сівби - 2,162,27 млн м² дн/га.

4. Інтенсивність фотосинтезу залежно від варіантів досліду коливалася: за рядкового способу сівби в межах від 11,55 мг $\mathrm{CO}_{2}$ дм²/год. до 12,40 мг $\mathrm{CO}_{2}$ дм ${ }^{2} /$ год., за широкорядного способу сівби від 11,33 мг $\mathrm{CO}_{2}$ дм²/год. до 12,06 мг $\mathrm{CO}_{2}$ дм²/год. Залежно від норми висіву та способу сівби листковий індекс становив для сортів відповідно: Романтика - від 3,89 до 4,13 м² листка/м², Устя - від 3,88 до 3,99, Ворскла - від 3,80 до 3,92 м листка/ $\mathrm{m}^{2}$.

бюлетень завершених наук. розробок «Аграрна наука - виробництву». - К. : УААН, 2005. C. 16.

5. Шевніков М. Я. Вплив мікроелементів на продуктивність сої / М. Я. Шевніков // Вісник Полтавської державної аграрної академії. - 2006. - №3. - C. 21-24.

6. Hanter M. N. Response of nine soybean line to soil moisture conditions close to saturation / M. N. Hanter, P. H. Jabrun, D. E. Byth // Austr.J. Exptl. Agris. Anim.Yusb., 1980. - V. 20. - P. 339.

7. Holberg S. F. Sojabean adaptation in Sweden / S. F. Holberg // World crops, 1956. - Vol. 8(3). P. 50-54. 